\title{
Effect of domestic processing and microwave heating on phenolic compounds and tannins in some oil seeds \\ El-Geddawy M.A.U. ${ }^{1}$, M.A. Sorour ${ }^{2}$, S.H. Abou-El-Hawa ${ }^{1}$, and E.M.M Taha ${ }^{3}$ \\ ${ }^{1}$ Food Science and Technology Department, Faulty of Agriculture, Assiut University \\ ${ }^{2}$ Food and Dairy Science Department Faulty of Agriculture, Sohag University \\ ${ }^{3}$ Food and dairy Tech. Department Faulty of Agriculture, south valley University
}

\begin{abstract}
Oilseeds contain different constituents with antioxidant activity especially phenolic compounds and tannins, this study was conducted to evaluate the possible effects of some domestic processes such as dehulling, soaking, ordinary and pressure cooking, germination, fermentation and microwave heating on the contents of phenolic compounds and tannins in some oilseeds. The data revealed that oil seeds could be considered as a rich source of oils and proteins. Phenolic compounds contents of raw oil seeds were; 978.4, 968.0, 862.75, 915.0 and $1063.4 \mathrm{mg} / 100 \mathrm{~g}$, while, tannin contents were; 510.0, 490.0, 457.0, 457.0 and 440.0 $\mathrm{mg} / 100 \mathrm{~g}$ on dry weight basis in peanut, sesame, soybean, safflower and sunflower, respectively. All processing treatments reduced the phenolic compounds except dehulling of sunflower seeds which was increased by $9.6 \%$. Dehulling of oil seeds reduced tannin content by $9-26.5 \%$, while during cooking processes, tannin leaching out in cooking water resulted in a reduction in its content by $4.5-19.6 \%$ for ordinary cooking and $5.2-20.2 \%$ for pressure cooking. Germination and fermentation processes decreased tannin by 12.5-34.7 and 13.6$49.0 \%$, respectively. Microwave heating treatment had an effect in removal of tannins from seeds than other cooking methods. The reduction ranged between $8.8-24.4 \%$ of its initial content in raw oil seeds. The study concluded that all processing treatments used in the study had an effect on the oilseeds content from both phenolic compounds and tannins.
\end{abstract}

Key words: Phenolic Compounds, microwave Heating, Domestic processing.

\section{INTRODUCTION}

Polyphenols constitute one of the most numerous and ubiquitous groups of plant metabolites and are integral part of both human and animal diets (Bravo, 1998). Oilseeds contain different substances with antioxidant activity, these are phenolic compounds such as hydroxylated derivatives of benzoic and cinnamic acid, coumarins, flavonoid compounds Oomah et al. (1995).

*Corresponding author: Eman Taha,

Email: e.taha@agr.svu.edu.eg

Received: December 1, 2019;

Accepted: December 9, 2019;

Published: December 10, 2019.
Phenolic compounds interact with dietary protein, digestive enzymes in the gut, resulting in variety of antinutritive and toxic effects Baxter et al. (1997). Tannins occurred in varying concentration in the oilseeds, which may be considered a major barrier to the use of the seed (Enujiugha and AyodeleOni 2003). Tannin are polyphenolic substances with various molecular weights and a variable complexity, these are chemically not welldefined substances but rather a group of substances with ability to bind protein in aqueous solutions (Makkar, 2003). Tannins 
may form soluble or insoluble complex with proteins (Mole and Waterman, 1987), minerals and vitamins Salunkhe et al. (1990) and reduce their bioavailability. Tannins in the diet not only precipitate in oral proteins, producing an astringent sensation but also interact with dietary proteins and digestive enzymes, resulting in a variety of antinutritive and toxic effects. In addition, this tannin reduces the bioavailability of vitamins (D'Mello, 1995). Tannins may protect plants from herbivory, increase resistance against pathogens or protect tissues against decay (Scalbert, 1991). The objective of the present study was an attempt to evaluate the effect of domestic processing and microwave heating on phenolic compounds and tannins as antinutritional factors in some oil seeds grown in Upper Egypt.

\section{Martials and methods}

\subsection{Materials:-}

The seeds of peanut (Arachis hypogaez:

L.) Giza-5 variety, sesame (Sesamum indicum L.) Giza-32 variety, soybean (Glycine max L. Merr.) Clark variety and safflower (Carthamus tinctorus L.) Giza-1 variety crop were obtained from Agronomy Department, Faculty of Agriculture, Assiut University (Summer) 1999. The seeds of sunflower (Helianthus annuus L.) Miack variety was obtained from Department of Oil Crops, Agriculture Research Center, Giza, Egypt. (Summer) 1999.

\section{Methods}

\subsubsection{Preparation of samples:}

Raw seeds: Whole dry seeds were manually cleaned from broken seeds, dust and other foreign materials and ground to 60 mesh flour size in an electric blender,
Dehulling: Clean seeds were soaked in distilled water $(1: 5 \mathrm{w} / \mathrm{v}$ seeds to water ratio) for 12 hours at room temperature, seed coats and germs were removed manually. The dehulled seeds were dried at $55^{\circ} \mathrm{C}$ for 30 hours.

Soaking: Clean seeds were soaked in tap water for 12 hours (seeds to water ratio 1:5 w/v). After soaking, the imbibed water was discarded. The soaked seeds were washed twice with ordinary water followed by rinsing with distilled water then dried in a hot air oven at $70^{\circ} \mathrm{C}$ for 36 hours.

Ordinary cooking: Clean seeds were put in round-mouthed tall bakers fitted with condensers, using a seeds to water ratio $(1: 7 \mathrm{w} / \mathrm{v})$. The samples were boiled to soft as silt between fingers. Cooked seed were dried at $70^{\circ} \mathrm{C}$ for 36 hours.

Pressure cooking: Clean seeds were autoclaved at $1.05 \mathrm{~kg} \mathrm{~cm}^{-2}$ pressure for 15 minutes. Dry seed to water ratio $(1: 2 \mathrm{w} / \mathrm{v})$ was used. The autoclaved seeds were mashed and then dried at $70^{\circ} \mathrm{C}$ for 36 hours.

Germination: The soaked seeds (12 hours) were germinated in sterile Petri-dishes lined with wet filter paper for 72 hours at room temperature, with frequent watering. The seed were rinsed with $0.3 \%$ sodium hypochlorite solution each 12 hour to inhibit microbial growth. The seedlings were then dried at $70^{\circ} \mathrm{C}$ for 36 hours.

Fermentation: The meal ground seeds were fermented for 24, 48 and 72 hours at $37^{\circ} \mathrm{C}$ using meal to water ratio $1: 4(\mathrm{w} / \mathrm{v})$ in stainless steel bucket. The fermented product dried in hot air oven at $70^{\circ} \mathrm{C}$ for 48 hours.

Microwave heating: Clean seeds were heated in microwave oven at the frequency, $9295 \mathrm{MHZ}$ for 1, 2 and 3 minutes. The samples were cooled at room temperature. 


\subsubsection{Analytical methods:}

2.2.1. Moisture, crude oil, ash, crude protein, crude fiber contents were determined according to (A.O.A.C,1990) Standard, Methods, while total carbohydrates were calculated by difference.

\subsubsection{Determination of phenolic compounds:}

The evaluation of phenolic compounds in samples was carried out according to the method described by (Ermakova, 1972). Two grams of each sample was extracted using 40 $\mathrm{ml}$ distilled water and heated in water bath at $100^{\circ} \mathrm{C}$ under condenser and agitated several times for 30 minutes. The mixture was quantitatively transferred to $100 \mathrm{ml}$ volumetric flask and filtered. The volume of $100 \mathrm{ml}$ distilled water and $25 \mathrm{ml}$ of indigo carmin were added to $10 \mathrm{ml}$ of supernatant. The mixture was well mixed and titrated with $0.1 \mathrm{~N}$ potassium permanganate solution until the appearance of yellow colour. The amount of phenolic compounds were calculated as follows: $1 \mathrm{ml} \mathrm{KMNO4} 0.1 \mathrm{~N}=4.6 \mathrm{mg}$ phenolic compounds. The indigo carmin solution was prepared by dissolving 1 gram indigo carmin in $50 \mathrm{ml}$ concentrated sulfuric acid and $500 \mathrm{ml}$ distilled water.

\subsubsection{Determination of tannin:}

Tannins were assayed according to modified vanillin-HC1 method of Price et al. (1978) as described by (Babiker and ElTinay 1992). Two grams of each sample was extracted with 50 nil absolute methanol for 20 minutes at room temperature with constant agitation. After centrifugation for 10 minutes at 653 r.p.m., $5 \mathrm{ml}$ of vanillin-HCI reagent was added to $1 \mathrm{ml}$ aliquots and the colour developed after 20 minutes at room temperature was read at $500 \mathrm{~nm}$. A standard curve was prepared using catechin (Sigma Chem. Co., St. Louis, Mo) after correcting for blank, tannins concentration was expressed in mg catechin equivalents.

\section{Results}

\subsection{Chemical composition of raw samples:-}

The contents of ash, oil, protein, crude fiber and carbohydrate are illustrated in Table 1. The results in same table indicated that, sunflower seeds contained the highest level of phenolic compounds compared to other seeds. The results are in good agreement with those reported by Pedrosa et al. (2000). It is clear that, tannins is a major phenolic compounds in oil seeds which the percentage of tannin from phenolic compounds is $52 \%$, $51 \%, 53 \%, 50 \%$ and $41 \%$ for peanut, sesame, soybean, safflower and sunflower, respectively. Similar findings were reported by (Brooker, 1999).

\subsection{Effect of processing on phenolic and tannin content}

Phenolic compounds and tannins in oil seeds under investigation were affected by technological processes such as dehulling, soaking, ordinary and pressure cooking, germination, fermentation and microwave heating as shown in Table 2.

Table (3): Effect of domestic processing on tannin content in studied oilseeds (mg / $100 \mathrm{~g})$

\subsubsection{Dehulling}

The results indicated that, removal of seed coat decreased the phenolic compounds content by $10.2-20 \%$ of its initial value of control in peanut, sesame, soybean, and safflower while dehulling of sunflower seeds caused an increase in phenolic compounds content by $9.6 \%$ of its content of control. The removal of seed coat led to decrease tannin content in dehulled oilseeds samples under investigation (Table 2). The decrement of tannin varied about 13.7, 26.5, 19, 10.2 and 
El-Geddawy et al., : SVU-International Journal of Agricultural Sciences, 1 (2): 23-32. 2019

9\% for peanut, sesame, soybean, safflower and sunflower, respectively, compared to control. These results are in agreement with those mentioned by (Sharma and Sehgal 1992).

Table (1): Chemical composition of some oilseeds (on dry weight basis) *.

\begin{tabular}{|c|c|c|c|c|c|c|c|}
\hline samples & $\begin{array}{l}\text { Ash } \\
(\%)\end{array}$ & $\begin{array}{l}\text { Crude } \\
\text { oil }(\%)\end{array}$ & $\begin{array}{l}\text { Protein } \\
(\%)\end{array}$ & $\begin{array}{l}\text { Crude } \\
\text { fiber }(\%)\end{array}$ & $\begin{array}{c}\text { Carbohydrate } \\
(\%)\end{array}$ & $\begin{array}{l}\text { Phenolic } \\
\text { compounds }\end{array}$ & $\begin{array}{c}\text { Tannin } \\
(\mathrm{mg} / 100 \mathrm{~g})\end{array}$ \\
\hline Peanut & 2.8 & 51.5 & 26.0 & 4.7 & 15.0 & אمصم/118.40 & 510.0 \\
\hline Sesame & 3.2 & 50.3 & 20.0 & 5.2 & 21.3 & 968.00 & 490.0 \\
\hline Soybean & 5.3 & 23.2 & 35.8 & 4.4 & 31.3 & 862.75 & 457.0 \\
\hline Safflower & 3.0 & 32.0 & 16.0 & 20.3 & 28.7 & 915.00 & 457.0 \\
\hline Sunflower & 3.6 & 45.0 & 20.0 & 7.0 & 24.4 & 1063.40 & 440.0 \\
\hline
\end{tabular}

Table (2): Effect of domestic processing on phenolic compounds in studied oilseeds (mg/100 )*

\begin{tabular}{ccccccc}
\hline Samples & Control & Dehulling & Soaking & $\begin{array}{c}\text { Ordinay } \\
\text { cooking }\end{array}$ & $\begin{array}{c}\text { Pressure } \\
\text { cooking }\end{array}$ & Germination \\
\hline Peanut & 978.40 & 807.10 & 658.30 & 660.40 & 611.00 & 606.60 \\
Sesame & 968.00 & 774.40 & 847.00 & 847.00 & 774.40 & 774.40 \\
Soybean & 862.75 & 775.00 & 675.00 & 650.00 & 625.00 & 625.00 \\
Safflower & 915.00 & 791.40 & 791.40 & 791.40 & 618.30 & 692.00 \\
Sunflower & 1063.40 & 1165.60 & 915.00 & 915.00 & 889.00 & 865.50 \\
\hline
\end{tabular}

* Mean values on dry weight basis.

\begin{tabular}{ccccccc}
\hline Samples & Control & Dehulling & Soaking & $\begin{array}{c}\text { Ordinary } \\
\text { cooking }\end{array}$ & $\begin{array}{c}\text { Pressure } \\
\text { cooking }\end{array}$ & Germination \\
\hline Peanut & 510.0 & 440.0 & 438.0 & 410.0 & 407.0 & 410.0 \\
Sesame & 490.0 & 360.0 & 390.0 & 440.0 & 410.0 & 320.0 \\
Soybean & 457.0 & 370.0 & 400.0 & 410.0 & 380.0 & 360.0 \\
Safflower & 457.0 & 410.0 & 440.0 & 430.0 & 410.0 & 400.0 \\
\multirow{2}{*}{ Sunflower } & 440.0 & 400.0 & 400.0 & 420.0 & 417.0 & 380.0 \\
\hline
\end{tabular}




\subsubsection{Soaking}

The results given in Table (2) showed that, soaking of seeds in tap water for 12 hours lowered phenolic compounds content compared with control. Soaking process reduced phenolic compounds content of seeds by 32.4, 12.5, 21.8, 13.5 and $14 \%$ for peanut, sesame, soybean, safflower and sunflower, respectively. The results presented in Table 3 showed that soaking of oilseeds lowered tannin content in seeds by $14,20.4,12.5 \%, 3.7$ and $9.1 \%$ for peanut, sesame, soybean, safflower and sunflower, respectively.

\subsubsection{Ordinary and Pressure Cooking}

Data in Table (2) indicated that, phenolic compounds decreased during ordinary cooking by $12.5-32.5 \%$ of its content in control. Similar finding was reported by Duhan et al. (1999) who stated that, processing methods including ordinary and pressure cooking caused decrease in polyphenolic content by $4-26 \%$ of pigeon pea seeds. The reduction of tannin was slightly higher(Table 3) under pressure cooked for 15 minute, with percentage of reduction $5.2-20.2 \%$ of its initial values. These results are in the line with mentioned by Ibrahim et al. (2002).

\subsubsection{Germination}

The results given in Table 2 showed that, phenolic compounds content decreased after germination of seeds for 3 days. The percentage of losses were; 38.0, 20.0, 27.5, 24.4 and 18.6\% of its initial values of control in peanut, sesame, soybean, safflower and sunflower, respectively. The results in Table 3 indicated that, germination of peanut, sesame, soybean, safflower and sunflower led to reduction of its tannins content compared with corresponding ungerminated samples. The reduction of tannins content was $12.5-34.7 \%$ of its initial value in raw seeds.

Table 4: Effect of microwave heating on phenolic compounds and tannin content in studied oilseeds

\begin{tabular}{|c|c|c|c|c|c|}
\hline Samples & Heating time (minute) & $\begin{array}{l}\text { Phenolic compounds } \\
\text { (mg/100g) }\end{array}$ & $\begin{array}{c}\text { Loss } \\
(\%)\end{array}$ & Tannin $((\mathrm{mg} / \mathbf{1 0 0 g})$ & $\begin{array}{c}\text { Loss } \\
(\%)\end{array}$ \\
\hline \multirow{4}{*}{ Peanut } & 0 & 978.40 & & 510.0 & \\
\hline & 1 & 488.90 & 13.6 & 420.0 & 17.6 \\
\hline & 2 & 800.00 & 18.2 & 400.0 & 21.6 \\
\hline & 3 & 780.00 & 20.3 & 400.0 & 21.6 \\
\hline \multirow{4}{*}{ Sesame } & 0 & 968.00 & & 490.0 & \\
\hline & 1 & 798.00 & 17.6 & 390.0 & 20.4 \\
\hline & 2 & 751.00 & 18.2 & 380.0 & 22.4 \\
\hline & 3 & 700.00 & 20.3 & 370.0 & 24.4 \\
\hline \multirow{4}{*}{ Soybean } & 0 & 862.75 & & 457.0 & \\
\hline & 1 & 751.00 & 13.0 & 380.0 & 16.8 \\
\hline & 2 & 700.00 & 18.9 & 380.0 & 16.8 \\
\hline & 3 & 670.70 & 22.3 & 370.0 & 19.0 \\
\hline \multirow{3}{*}{ Safflower } & 0 & 915.00 & & 457.0 & \\
\hline & 1 & 845.00 & 7.6 & 417.0 & 8.8 \\
\hline & 2 & 765.00 & 16.4 & 400.0 & 12.4 \\
\hline \multirow{5}{*}{ Sunflower } & 3 & 707.00 & 22.7 & 400.0 & 12.4 \\
\hline & 0 & 1063.40 & & 440.0 & \\
\hline & & 821.00 & 22.8 & 390.0 & 11.4 \\
\hline & 1 & 798.00 & 25.00 & 370.0 & 16.0 \\
\hline & 2 & 751.00 & 29.4 & 360.0 & 18.2 \\
\hline
\end{tabular}

*Mean values on dry weight basis 


\subsubsection{Microwave Heating}

The effects of microwave heating on phenolic compounds and tannins content in oilseeds are shown in Table 4. The results indicated that, microwave heating for 1,2 and 3 minutes decreased the level of phenolic compounds by 13.6-20.3, 17.6-27.7, 13-22.3, 7.6-22.7 and $22.8-29.4 \%$ for peanut, sesame, soybean, safflower and sunflower, respectively.

\subsubsection{Fermentation}

The results in Table (5) illustrate the effect of fermentation for 24,48 and 72 hours on phenolic compounds in some oilseeds. Fermentation process of oilseeds led to decrease in phenolic compounds content by 25.7-31.7, 28-28.7, 13.418.8, 12.7-15.4 and $19.4-30.3 \%$ for peanut, sesame, soybean, safflower and sunflower, respectively. The effect of natural fermentation on tannin content are summarized in Table 5. Fermentation resulted in loss of tannins by 23.5-43, 24.4-49, 19-47.5, 21.2-45.3 and 13:6$47.7 \%$ for peanut, sesame, soybean, safflower and sunflower, respectively. From the data illustrated in Table 5 it could be observed that, the reduction of tannins content was increased gradually during fermentation time. The reduction of tannin as percentage was higher at the end of fermentation time (72 hours). Similar finding was reported by Granito et al. (2002) who found that, natural fermentation of flour and whole bean seeds (Phaseolus vulgaris) for 48 hours at $42^{\circ} \mathrm{C}$ decreased tannins content by $61-70 \%$. Fermentation of oil seeds meal caused a reduction of tannins content from 20 to $10 \mathrm{~g} / \mathrm{kg}^{\prime} 1$ ( Mukhopadhyay and Ray 1999)

Table 5:Effect of fermentation on phenolic compounds and tannin content in studied oil seeds

\begin{tabular}{|c|c|c|c|c|c|}
\hline Samples & $\begin{array}{l}\text { Fermentation } \\
\text { time(mim) }\end{array}$ & $\begin{array}{l}\text { Phenolic } \\
\text { compounds }\end{array}$ & $\begin{array}{l}\text { Loss } \\
(\%)\end{array}$ & $\begin{array}{l}\text { Tannin } \\
(\mathrm{mg} / 100 \mathrm{~g})\end{array}$ & $\begin{array}{l}\text { Loss } \\
(\%)\end{array}$ \\
\hline \multirow[t]{4}{*}{ Peanut } & 0 & 978.40 & - & 510.0 & - \\
\hline & 24 & 726.30 & 25.7 & 390.0 & 23.5 \\
\hline & 48. & 677.80 & 30.7 & 310.0 & 39.0 \\
\hline & $\begin{array}{c}72 \\
0\end{array}$ & $\begin{array}{l}668.30 \\
968.00\end{array}$ & $\begin{array}{l}31.7 \\
-\end{array}$ & $\begin{array}{l}290.0 \\
490.0\end{array}$ & $\begin{array}{c}43.0 \\
-\end{array}$ \\
\hline \multirow{3}{*}{ Sesame } & 24 & 697.70 & 28.0 & 370.0 & 24.4 \\
\hline & 48 & 697.70 & 28.0 & 360.0 & 26.5 \\
\hline & 72 & 690.40 & 28.7 & 250.0 & 49.0 \\
\hline \multirow[t]{3}{*}{ Soybean } & 0 & 862.75 & - & 457.0 & - \\
\hline & 24 & 747.50 & 13.4 & 370.0 & 19.0 \\
\hline & 48 & 742.50 & 13.9 & 370.0 & 19.0 \\
\hline \multirow[t]{4}{*}{ Safflower } & $\begin{array}{c}72 \\
0\end{array}$ & $\begin{array}{l}700.70 \\
915.00\end{array}$ & $\begin{array}{c}18.8 \\
-\end{array}$ & $\begin{array}{l}240.0 \\
457.0\end{array}$ & $\begin{array}{l}47.5 \\
-\end{array}$ \\
\hline & 24 & 798.80 & 12.7 & 360.0 & 21.2 \\
\hline & 48 & 790.40 & 13.6 & 350.0 & 23.4 \\
\hline & 72 & 774.60 & 15.3 & 250.0 & 45.3 \\
\hline \multirow[t]{4}{*}{ Sunflower } & 0 & 1063.40 & - & 440.0 & - \\
\hline & 24 & 856.60 & 19.4 & 380.0 & 13.6 \\
\hline & 48 & 760.30 & 28.5 & 340.0 & 22.7 \\
\hline & 72 & 740.40 & 30.3 & 230.0 & 47.7 \\
\hline
\end{tabular}

*Mean values on dry weight 


\section{Discussion}

\subsection{Chemical composition of raw samples}

The analysis of gross chemical composition of oil seeds under investigation showed that, all studied samples could be considered a rich source of oils and proteins.

\subsection{Effect of processing on phenolic and tannin content}

\subsubsection{Dehulling}

Removing of seed coat decreased the phenolic compounds content, the results appeared that both hull and kernel contained polyphenols but the kernel contained slightly higher concentration. Pawar et al. (2001) reported that, Dehulling process increased the relative polyphenols by $6.3 \%$ indicating that they were primarily present in the kernels. The results were the same for tannin content. However the highest decrement of tannin content was observed in dehulled sesame seeds compared with other oilseeds. It could be suggested that tannins occurred in the hull parts (El-Shemyl 996).

\subsubsection{Soaking}

The loss in phenolic compounds level of the seeds during soaking might be attributed to the leaching out into soaking water under the concentration gradient (Kataria et al. 1989 , Kaur and Kapoor 1990).

Tannin content also decreased by soaking, this decrease in the tannin content might be attributed to the leaching out in soaking water or its hydrolysis by enzymes during soaking period (Desphande and Cheryan, 1983)

\subsubsection{Ordinary and pressure cooking}

The reduction in phenolic compound by ordinary and pressure cooking might be due to the binding of phenolic compounds with other organic substances and protein or to alteration in the chemical structure of phenolic compounds which could not be extracted by a variable methods Bishnoi el al. (1998).

\subsubsection{Germination}

Germination process caused a reduction in both phenolic and tannin content the reduction of phenolic compounds might be attributed to the presence of polyphenol oxidas and enzymatic hydrolysis (Rao and Deosthale,1982 and Jood et al. 1987). while the loss of tannin content during germination of oil seeds might be due to enzymatic hydrolysis (Rao and Deosthale, 1982).

\subsubsection{Microwave heating}

The content of phenolic compounds decreased by increasing the time of microwave heating treatment. As other heat treatment the decrease might be due to binding of phenolic compounds with other organic substance and protein or change in the chemical structure of phenolic during microwave heating Bishnoi et al. (1998). From these results it is clear that the application of dry heat on seeds in many cases was not effective in reducing the phenolic compounds content compared to moist heating involving ordinary and pressure cooking. Microwave heating had more effective function in removal of tannins content from seeds than other cooking methods. Similar finding was reported by (Sorour, 2002) who found that, microwave heating for 6 minutes significantly decreased the concentration of tannin of legumes by 2938\%. Furthermore, (Habiba, 2002) showed that, maximal reduction in tannin content occurred after microwave heating of peas for 12 minutes compared with ordinary and pressure cooking.

\subsubsection{Fermentation}

The reduction of phenolic content as a result of fermentation process might be due to the activities of the intrinsic oxidatize enzymes 
under fermentation condition. The phenols were oxidized and the resulting compounds associated reversibly with proteins by hydrogen bonds or, irreversibly by condensation with reactive groups of amino acids, peptides, proteins and polysaccharides Bartolome et al. (1995).For the reduction of tannin content as a result of fermentation process . Bhat et al. (1998) revealed that, the loss of tannin during fermentation of seeds perhaps due to the action of enzymes which tannase, a key enzymes in the degradation of tannins is present in diverse groups of microorganisms.

\section{Conclusions}

It was widely accepted that simple and inexpensive processing techniques such as dehulling, soaking, ordinary and pressure cooking, germination, fermentation and microwave heating were effective methods for reducing the levels of phenolic compounds and tannins in the aforementioned studied oil seeds. Furthermore, it was essential to improve the nutritional quality of seed meals and effectively utilize their full potential as human food

\section{Acknowledgement}

The authors gratefully acknowledge faculty of Agriculture, South Valley University, Egypt, for supporting this project financially. A great acknowledgment also goes to Agronomy Department, Faculty of Agriculture, Assiut University and Department of Oil Crops, Agriculture Research Center, Giza, Egypt for their generous assistance and providing the matrials during the study.

\section{Declarations}

The authors declare that they have no conflect of interests

This article had been previously published at The 4th Scientific Conference of Agricultural Sciences, Assiut, December, 2004

\section{REFERENCES}

A.O.A.C, (1990) 'Official Methods of Analysis $\left(15^{\text {th }}\right.$ Ed.)', Association of official Analytical Chemists. Washington.D. C.

Babiker, E.E. and El-Tinay, A.H. (1992) 'Effect of alkali on tannin content and in vitro protein digestibility of sorghum cultivars', Food Chem. 45: 55.

Bartolome, B., Jimenzez-Ramsey, L.M. and Butler, L.G. (1995) 'Nature of condensed tannins present in the dietary fiber fractions in foods', Food Chem. 53 (4): 357-362.

Baxter, N.J., Lilley, Ti-I., Haslam, E. and Williamson, N.P, (1997) 'Multiple interactions between polyphenols and salivary prolin- rich protein repeat result in complexation and precipitation', Biochem, 36 (18): 55665572.

Bhat, T.K., Bhupinder, S. and Sharma, O.P. (1998) 'Microbial degradation of tannins-A current perspective', Biodegradation. 9 (5): 343-357.

Bishnoi, S., Saro, J. and Khetar, P. (1998) 'Content of polyphenols in cultivars as affected by various processing and cooking methods', $2^{\text {nd }}$ International Electronic Conference on Synthetic Organic Chemistry (ECSOC-2).

Bravo, L. (1998) 'Polyphenols: Chemistry, dietary sources, metabolism, and nutritional significance', Nutr Rev. 56 (11): 317-333.

Brooker, J.D. (1999) 'Tannin Livestock and Human nutrition. International Workshop Held in Adelaide, Australia. 
D'Mello, J.P.F. (1995) 'Antinutritional substances in legume seeds. In J. P. F D'Mello and C. Devendra, eds. Tropical legumes in animal nutrition' Walling Food, Uk, CAB international. P. 135172.

Deshpande, S.S. and Cheryan, M. (1983) 'Changes in phytic acid, tannins and trypsin inhibitory activity on soaking of dry beans (Phasedus vulgaris L.)' Nutr. Rep. Int., 27: 371.

Duhan, A., Khetarpaul N. and Bishnoi, S. (1999) 'Effect of Various domestic Processing and cooking methods on phytic acid and Hcl-extractability of calcium, phosphorus and iron of pigeon pea' Nutr. Health. 13 (3): 161-169.

El-Shemy, H.A. (1996) 'Biochemical studies on some antinutrtional factors', Ph. D. Thesis, Faculty of Agriculture, Cairo University.

Enujiugha, V.N. and Ayodele-oni, Oni. (2003) 'Evaluation of nutrients and some anti-nutrients in lesser-known, underutilized oilseeds' Inter. J. Food Sci. Tech. 38 (5): 625.

Ermakova, A.U. (1972) 'Methods of analysis of plant biochemistry' Leningrad "Koloc", USSR 450 PP.

Granito, M., Frias, J., Doblado, R., Guerra, M., Champ, M. and Vidal-Valverde, C. (2002) 'Nutritional improvement of beans (Phaseolus vulgaris) by natural fermentation' Eur. Food. Res. and Techol. 214 (3): 226-231.

Habiba, R.A. (2002) 'Changes in antinutrients, protein solubility digestibility, and Hclextractability of ash and phosphorus in vegetable peas as affected by cooking methods' Food Chem. 77 (2): 187-192.

Ibrahim, S.S., Habiba, R.A., Shatta, A.A. and Embaby, H.E. (2002) 'Effect of soaking, germination and fermentation on anti- nutritional factors in cowpeas' Nahrung. 46 (2): 92-95.

Jood, S., Chauhan, B.M. and Kapoor. A.C, (1987) 'Polyphenols of chickpea and black gram as affected by domestic processing and cooking methods' J. Sci. Food Agric. 39 (2): 145-150.

Kataria,, A., Chauhan, B.M. and Punia, D. (1989) 'Antinutrients in amphidiploids (black grarnx mungbean): varietal differences and effect of domestic processing and cooking' plant foods Hum Nutr. 39 (3): 257-266.

Kaur, D. and Kapoor, A.C. (1990) 'Some Antinutritional factors in Rice bean(Vigna umbellata): Effects of domestic processing and cooking methods' Food Chem. 37: 171-179.

Makkar, H.P.S. (2003) 'Effects and fate of tannins in ruminant animals, adaptation to tannins', and strategies to overcome detrimental effects of feeding tanninrich feeds' Small Ruminant Research 49: 241-256.

Mole, S. and Waterman, P.G. (1987) 'Tannic acid and proteolytic enzymes: enzyme inhibition or substrate deprivation' Phyto chem. 26: 99-102.

Mukhopadhyay and Ray. (1999) 'Effect of fermentation on nutritive value of sesame seed meal in the diets for rohu, labeo rohita (Hamilton), fingerlings' Aquaculture Nutrition. 5 (4): 229.

Oomah, B.D., Kenaschuk, E.O. and Mazza, G. (1995) 'Phenolic acids in flax seed' $J$. Agrtic. Food Chem. 43: 2016-2019.

Pawar, V.D., Patil, J.N., Sakhole, B.K. and Agarkar, B.S. (2001) 'Studies on nitrogen extractability of defatted sunflower meal' J. Food Sci. Technol. 38 (3): 217219

Pedrosa, M.M., Muzquiz, M., Garcia Vallejo, C, Burbora, G., Cuadrado, C., Ayet, G. and Roberdo, L.M. (2000) 
'Determination of caffeic and chlorogenic acids and their derivatives in different sunflower seeds' J. Scin. Food and Agri. 80 (4): 459-764.

Price, M.L., Scogoc, V.S. and Butler, L.G. (1978) 'A critical evalution of the vanillin reaction as an assay for tannin in sorghum grain .1' Agric. Food Chem. 26: 1214.

Rao, P.V. and Deosthale, Y.G. (1982) 'Tannin content of pulses; Varietal differences and effects of germination and cooking' J. Sci. Food Agric. 33: 1013-1016.

Salunkhe, DX., Chavan, J.K. and Kadam, S.S. (1990) 'Dietary Tannins: consequences and Remedies' Boca Raton, FL: CRC Press.

Scalbert, A. (1991) Antimicrobial properties of tannins phytocheinistry 30: 38753883. [Cross Ref.].

Sharma, A. and Sehgal, S. (1992) 'Effect of domestic processing, cooking and germination on trypsin inhibitor activity and tannin content of faba bean (Vicia Abel)' Plant Food Hum Nutr. 42 (2): 127-133.

Sorour, M.A.H. (2002) 'Antinutritional factors and protein digestibility of some common legumes as affected by processing and microwave treatment' Arab Mansoura Conference of Food and Dairy Science Technology. Faculty of Agriculture, Mansoura University, Egypt. (1-3 October 2002). 